\title{
化粧品講座 (第VI講)
}

（色材，63 [1] 40 45. 1990）

\section{化粧品 の機 能 性 評価}

\section{（I）官 能 評 価}

\section{1. は じめに}

化粧品を使用する場合，その目的はクリーム，乳液な どの基礎化粧品を用いて皮膚の状態を改善したり,ブァ ンデーション，口紅等のメーキャップ製品を用いて自分 をより美しく表現することである。このような目的で使 用される化粧品の効果あるいは使用特性等は, 消費者の 感覚的な評価によりその製品の良し悪しが判定されてい る部分が大きいと思われる。

従って, 従来より化粧品開発に执いては官能検査が重 要な位置を占めて和り，これまで多くの報告がなされ

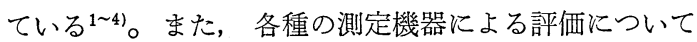
も検討されているが2,5)，化精品の評価に䄧いては嗼好る 非常に重要な要素であり,「硬さ」「のび」などの物性的 な評価にも大きく影響している。このようなことから， 各種の機器測定による評価は官能検查の補助として用い ることはできるが，官能検查に置き換えることは困難で あろら。

この人の感覚によってなされる官能評価においては, 官能評価用語のあいまいさ, 評価の信頼性 (再現性), 評価傾向の相違等いくつかの 注意すべき点がある6)。従 って,より客観的な評価を行うためには評価用語の具体 的な定義を明確にするとともに，事前にパネルの評価特 性を把握しておく必要がある。

官能評価用語のあいまいさの一例として, 基礎化粧品 (クリーム)の「のび」および「しっとり感」について 各パネルが具体的にどのような判断基準で評価している か調べた結果を表-1 に示した。

表-1 から分るよらに，「のび」における判断基準は

平成 1.8 .2 受理

Evaluation on the Efficacy of Cosmetics

( I ) Sensory Evaluation

* 鐘紡(株)化粧品研究所

神奈川県小田原市寿町 5-3-28（干250）
林 照 次*小野 正 宏*

「伸ばすときの抵抗が少なく，広く塗布できる」(83\%) で比較的一致した評価がなされている。一方，「しっと り感」に执いては各パネルに和いて評価の判断基準がか なり異なって敊り，全く相反する評価をしているパネル も見受けられる。クリーム等の評価においては, 一般的 に塗布前拉よび塗布初期の感覚である「光沢」「とれ」「硬 さ」「のび」といった項目に扮いては具体的な評価感覚 が比較的明確であるため評価の信頼性拉よび一致性が高 い。しかしながら，塗布後の感覚である「しっとり感」 「収まり」等の項目に㧤いては, 評価用語の具体的表現 が難しいこともあり, 評価データの信頼性および評価傾 向の一致性は低い。

そこで今回は, この評価データの信頼性およびパネル メンバー間の評価傾向の差異について, 実際にどのよう な状況にあるのかをクリームを用いて調査した結果を例 として報告し, 評価データのチェック，パネルの育成等 を含めたより客観的な評価システムの構築について考兄 てみたい。

\section{2. 調 查 方 法}

\section{1 調查概要}

調查概要を表-2 亿示した。アンケート調査では, サン 表-1 官能評価用語「のび」「しっとり感」の判断基準

\begin{tabular}{|c|c|c|c|}
\hline \multicolumn{2}{|c|}{ び } & \multicolumn{2}{|l|}{ しっとり感 } \\
\hline $\begin{array}{l}\text { 伸ばすときの抵抗が } \\
\text { 小さい }\end{array}$ & $64 \%$ & $\begin{array}{l}\text { 塗布後, 油性感が大 } \\
\text { きい }\end{array}$ & $18 \%$ \\
\hline $\begin{array}{l}\text { 一定量で抵抗なく塗 } \\
\text { 布できる広さ }\end{array}$ & $19 \%$ & $\begin{array}{l}\text { 塗布後, 油性感が小 } \\
\text { さい }\end{array}$ & $12 \%$ \\
\hline $\begin{array}{l}\text { すばやく透明に擦り } \\
\text { 込める }\end{array}$ & $7 \%$ & $\begin{array}{l}\text { 塗布後，肌がみずみ } \\
\text { ずしく見える }\end{array}$ & $26 \%$ \\
\hline 均一に塗布できる & $2 \%$ & 塗布後, 指で振れた & $23 \%$ \\
\hline その他 & $8 \%$ & $\begin{array}{l}\text { 時, 揤抗が大きい } \\
\text { 塗布後肌の柔軟性, } \\
\text { 弾力性が大きい }\end{array}$ & $19 \%$ \\
\hline & & その他 & $2 \%$ \\
\hline
\end{tabular}


表-2 調 査 概 要

[アンケート調査 $]$ ・対比較法 - 順位法

[解析]

\begin{tabular}{l|c|c}
\hline & 一対比較法 & 順 位 法 \\
\hline 信頼性調査 & 一意性の㭘定 & 2 回の順位相関 \\
一致性評価 & 一致性の検定 & 一致性の検定 \\
評価傾向分類 & クラスター分析 & クラスター分析 \\
\hline
\end{tabular}

プル 5 品を用いて一対比較法および順位法の 2 通りの手 法で行った。また, 得られた官能検査データの解析とし ては,

1）データの信頼性調查として, 一対比較法では一意 性の検定, 順位法では 2 回の順位相関を調べた。

2) パネル全体としての評価の一致性調査として一致 性の検定を行った。

3） パネルメンバー間の評価傾向が実際にどのように 異なるかを調べるために，クラスター分析によりパネル をグループ化し, 各グループの存在比率がどのようにな っているかを調べた。

\section{2 官能検查}

サンプルは自社製品処方より色材成分を除き，それぞ れに同一香料を配合したもの 5 品を用いた。パネルは社 内外のボランティアを対象に, 一対比較法は 122 名, 順 位法は 68 名で行った。

一対比較法に拈いては, 各パネルはサンプル 5 品のな かの 2 品のすべての組合せ (10 組) について, 8 項目 （光沢, とれ, 硬さ, リッチ感, のび, ベたつき, しっと り感, 収まりの各項目) の評価および総合評価を行っ た。また，この試験では各項目の評価は 6 段階に設定し ているが，単に優劣比較でもよい。

順位法は, 一対比較法と同じサンプル 5 品を用いて行 い, 各サンプルの順位を回答させた。また，順位法は評 価の再現性をみるためにサンプルの記号を変えて 2 回実 施した。

参考までに，一対比較法および順位法に括けるアンケ ート用紙の一部を図ー1, 図-2 に示した。

\section{3 解析方法}

\subsection{1 評価の信頼性調査}

各パネルメンバーの評価の信頼性すなわち, 各評価項 目においてサンプルが実際どの程度識別されているのか を調べるために，一対比較法では一意性の係数, 順位法 では 2 回の評価の順位相関 (Kendall) を調べた。

\subsection{2 パネルの評価傾向の調査}

パネルメンバー間の評価が実際にどのように異なるの
クリーム官能調查アンクート

[記人方法]1番のクリームを基準にして2番のクリームを評価し、 下記の各項目について該当する番号に○印を記入して下さい。



図-1 一対比較法に和けるアンケート

クリーム官能調查アンケート 試験方法

○試料 5 点（FGHIJ) について、アンケートの各項目ごとに 1 位〜 5 位 の順位を付け、回答例を参考にして試料の記号を記入して下さい。

\begin{tabular}{|c|c|c|c|}
\hline *回答例 & ある & $\begin{array}{c}12345 \\
()()()()()\end{array}$ & ない \\
\hline 評価項目 & & 順 位 & \\
\hline & & $\begin{array}{lllll}1 & 2 & 3 & 4 & 5 \\
\end{array}$ & \\
\hline [ 光沢 ] & ある & ()()()()() & ない \\
\hline 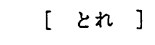 & とりやすい & $(x)()()()$ & とりにくい \\
\hline & & & \\
\hline [総合評価] & 良い & ()()()()() & 悪い \\
\hline
\end{tabular}

図-2 順位法に拈けるアンケート

か，その程度および傾向を把握しておくことも重要であ る。

そこで，まずパネル全体としての評価傾向のばらつき 調査として，一対比較法に打ける一致性係数执よび順位 評価における Kendall の一致性係数を調べた。

次に,より具体的に，どのように評価する人がどの程 度の比率で存在するかを知るために各評価項目について それぞれクラスター分析を実施した。これにより，パネ ルを評価の類似する者同志，客観的にグループ分けし， グループ間の差異, 各グループの構成比率を調べた。

\section{3. 結 果}

\section{1 評価の信頼性調査}

一対比較法に拈けるクリームの各評価項目において, 各パネルメンバー間の評価の信頼性を調ベた一意性係数 の結果を表-3 に示した。

一意性係数が 1 のパネルは, 10 通りの評価において 
表-3 一対比較法における一意性係数の分布

\begin{tabular}{|c|c|c|c|c|c|c|c|c|c|c|c|c|c|c|c|}
\hline & \multicolumn{14}{|c|}{ 評 } \\
\hline & & 光 & 沢 & と & れ & 硬 & さ & リッチ感 & の & び & ベたつき & しっとり感 & 収 & ま & \\
\hline \multirow{6}{*}{$\begin{array}{l}\text { 意 } \\
\text { 性 } \\
\text { 係 }\end{array}$} & 1 & & 7名 & & 2 & & 4 & 53 & 63 & & 47 & 35 & & 40 & \\
\hline & 0.8 & & 8 & & & & 8 & 18 & 23 & & 24 & 10 & & 13 & \\
\hline & 0.6 & & 1 & & 8 & & 7 & 24 & 18 & & 24 & 31 & & 24 & \\
\hline & 0.4 & & 5 & & 9 & & 0 & 11 & 10 & & 15 & 19 & & 23 & \\
\hline & 0.2 & & 9 & & 9 & & 0 & 13 & 8 & & 9 & 19 & & 20 & \\
\hline & 1 & & 2 & & 3 & & 3 & 3 & 0 & & 3 & 8 & & 2 & \\
\hline \multicolumn{2}{|c|}{0.4 以下 } & & $1 \%$ & & & & 9 & 22 & 15 & & 22 & 38 & & 37 & \\
\hline
\end{tabular}

表-4 順位相関係数の分布

\begin{tabular}{|c|c|c|c|c|c|c|c|c|c|c|}
\hline & \multicolumn{10}{|c|}{ 評 } \\
\hline & 光 沢 & と れ & 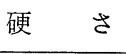 & リッチ感 & の & び & ベたつき & しっとり感 & 収ま & り \\
\hline $0.8 \sim 1$ & 33名 & 25 & 34 & 19 & & 29 & 19 & 23 & 25 & 5 \\
\hline $0.4 \sim 0.6$ & 24 & 22 & 25 & 21 & & 26 & 15 & 19 & 21 & \\
\hline$\leqq 0.2$ & 11 & 21 & 9 & 28 & & 13 & 24 & 26 & 32 & 2 \\
\hline$\leqq 0.2$ の比率 & $16 \%$ & 31 & 13 & 41 & & 19 & 35 & 38 & 4 & 7 \\
\hline
\end{tabular}

表-5 評価傾向の一致性

\begin{tabular}{|c|c|c|c|c|c|c|c|c|}
\hline & \multicolumn{8}{|c|}{ 評 } \\
\hline & 光 沢 & と林 & 硬さ & リッチ感 & の & ベたつき & しっとり感 & 収まり \\
\hline 一対比較法 & 0.46 & 0.16 & 0.18 & 0.36 & 0.49 & 0.38 & 0.18 & 0.13 \\
\hline 順位法 1 回目 & 0.66 & 0.52 & 0.68 & 0.31 & 0.60 & 0.45 & 0.08 & 0.24 \\
\hline 2 回目 & 0.69 & 0.54 & 0.70 & 0.32 & 0.69 & 0.33 & 0.08 & 0.27 \\
\hline
\end{tabular}

* 順位法 : Kendall の一致性計数

全く矛盾なく回答しているパネルであり, 平均として約 40\%のパネルメンバーが含まれる。一方，一意性係数が 低いパネルは，矛盾を多く含んだ回答をしているパネル であり, データの信頼性は低い。一意性係数が 0.4 以下 のパネルは平均として $25 \%$ であった。

評価項目別にみると, 外観およびクリーム使用初期の 感覚である光沢, 硬さ, のびの各項目では比較的良く識 別されているが, 塗布後の感覚であるしっとり感, 収ま りではあいまいな評価をしているパネルメンバーが多い ことが分かる。

次に，順位法で実施した 2 回のクリーム評価におい て, 各評価項目の順位相関係数を表-4 に示した。

順位相関係数が 1 のパネルは, 2 回の評価において全 く同じ順位で回答しているパネルであり, 評価の信頼性 （言いかえれば評価能力）が高い。一方, 順位相関係数が 低い 0.2 以下のグループには, 平均して $30 \%$ のパネル
が含まれた。

なお，評価の信頼性の低いパネル（一対比較法では一 意性係数が 0.4 以下のパネル, 順位法では順位相関係数 が 0.2 以下のパネル） は以降の一致性の検定およびク ラスター分析に新いて解析の対象から除外した。

\section{2 評価傾向の一致性}

パネル 全体の評価傾向がどの程度ばらついているかを 知るために, 一対比較法および順位法における一致性係 数について調べた結果を表-5 に示した。

表-5 の各項目において，「しっとり感，「収まり」の 項目に和いては, 一対比較法および順位法共に一致性係 数は低く, パネルメンバーにより評価傾向がかなり異な っていることが分かる。また，「とれ」，「硬さ」の項目に おいては, 一対比較法と順位法では相当異なった結果が 得られ, 一詨比較法では評価傾向がばらついているのに 対して, 順位法ではかなり一致した傾向を示した。他の 
項目では, 一対比較法拉よび順位法共に比較的一致した 傾向を示した。

\section{3 クラスター分析結果}

パネルメンバー間の評価傾向が具体的にどのように異 なるかを調べるために，一対比較法における評価データ

を用いてクラスター分析を行い, 各評価項目において 5
グループに分類した。なお，クラスター計算に拈いて必 要なパネルメンバー間の距離としては，（1）式で示す ニークリッド距離を用い, 融合方法は Ward 法とした。

$$
D(1,2)^{2}=\sum_{i}\left\{A_{i}(1)-A_{i}(2)\right\}^{2}
$$
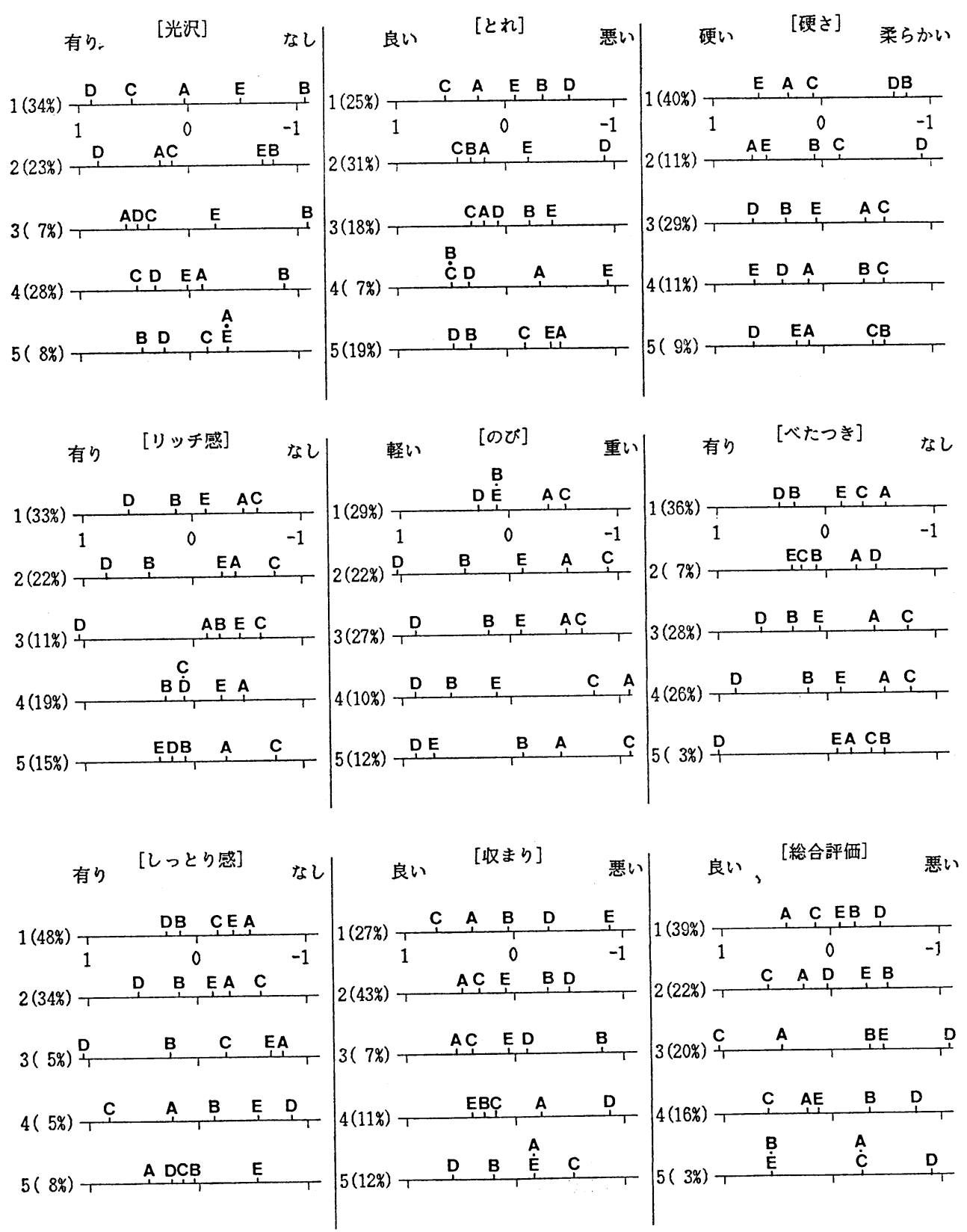

図-3 クラスター分析による分類 
$1,2:$ パネル

$A_{i}(1)$ : パネル 1 の $i$ にいての評価

各評価項目について分類した 5 グループについて, グ ループ別にサンプルの評価を集計した結果を図-3に示 した。

一致性係数の低い「とれ」「硬さ」「しっとり感」「収ま り」の各項目においては,グループによって評価が大き く異なっている。例えば「硬さ」の項目に妨いては, グ ループ $1 ， 2$ とグループ $3 ， 4 ， 5$ ではサンプル $D$ に対 する評価が正反対になっている。これは, 実際に評価し ている感覚が硬さという表現だけでは厳密に規定され ず，パネルメンバーによって微妙に異なっているためと 考えられる。このように, パネル全体として評価傾向が 大きくことなる場合には, 評価語の定義の再検討および パネルの教育等を行う必要があると思われる。

また，「しっとり感」に拈けるグループ 4 抹よび「収 まり」に和けるグループ 5 のよらに, 少人数ではあるが 他のグループとは全く異なった評価をするグループが存 在している場合がある。このような場合には，異なった 評価をしているパネルについて教育する必要がある。

\section{4 パネルの評価能力について}

今回報告した一対比較法に打ける一意性の係数および 2 回の順位評価における順位相関係数は, アンケート調

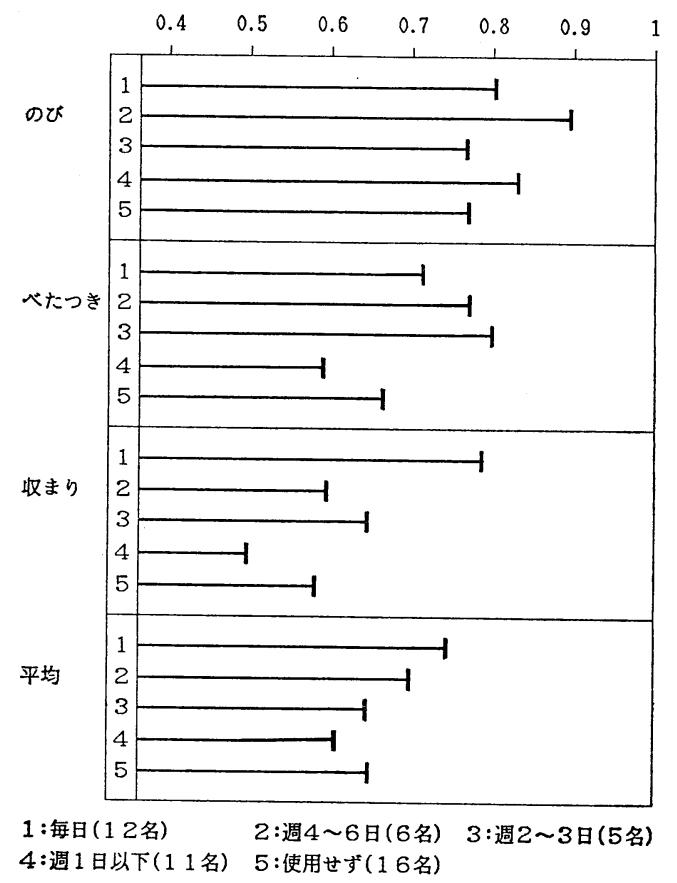

図-4 クリーム使用頻度別一意性
査で得られたデータの信頼性をチェックするために用い た。この一意性係数之順位相関係数はまた, 各パネルメ ンバーの評価能力を示す指標と考えることもできる。

一例として, 女性 50 名をクリームの使用頻度により 5 グループに分類し, 代表的項目および 8 項目平均につ いて，各グループの一意性係数を調べた結果を図-4に 示した。

傾向は評価項目によって異なるが，全体的には使用頻 度が高いほど, 評価の信頼性は高いと考えられる。

\section{4.より客観的な官能評価を求めて}

最初に述べたように, 官能評価を行う際に注意すべき 事項として，1）官能評価用語のあいまいさ，2）評価デ ータの信頼性チェック，3）パネルメンバー間の 評価傾 向の相違等がある。また, 評価の精度を向上させるため には,パネルの教育も重要な問題である。

より客観的な官能評価を行うために, 特に日常的に官 能評価を行っている機関において実施すべき手順とし て, 今回述べた解析方法を用いた一例をまとめてみる 之,

1）各評価用語について具体的な定義を明確にし，各 パネルに周知徹底させる。

2）一対比較法, 順位法等により, 各パネルおよび各 評価項目について評価データの信頼性をチェックする。 また, 信頼性の低いパネルについては, 評価用語の定義 と実際の感覚とが対応するよう再教育を行う。

3）評価傾向の一致性の検定により，パネル全体とし ての評価傾向のばらつきをチェックする。

4) クラスター分析等により, 個々のパネルについて 評価傾向を把握する。

3)，4）において，パネル全体に括いて評価傾向がばら つく場合は, 主として官能評価用語のあいまいさに問題 があると思われる。従って, 評価用語の定義を再検討 し, 評価する時の実際の感覚として分りやすい表現にし た後, 再度評価の信頼性および評価傾向のチェックを行 ら。また，一部のパネルが他の大部分のパネルと異なっ た評価傾向を示す場合は, 異なった傾向を示すパネルに ついて判断基準のずれを説明し, 評価用語の定義に対応 した感覚を習得させる。

いずれにしても，官能評価においては優れた評価パネ ルの育成, 確保が重要であり, そのようなパネルによっ て評価されたデータを用いた場合に，はじめて各種の有 意差検定に意味があるものと思われる。 


\section{文献}

1）梅沢伸嘉：ハンドクリームのフィーリング評定, 日本化粧品技術者連合会会誌，61（2），21～27 (1970)

2）鈴木一成：化粧用クリームのレオロジー的性質と 官能評価の関係，フレグランスジャーナル， 8, 78〜83 (1974)

3) K. Morosawa, C. Ohtake, M. Takahashi, T. Mitsui, S. Ishikawa : A Studay on the Differential Thresholds of Sensory "Firmness" and "Viscousness" of Cream Base Substances, $J$.
Soc. Cosmet. Chem., 27, 481 494 (1974)

4）日科技連官能検查委員会: “新版 官能検査ハン ドブック”p. 301, 日科技連 (1973)

5) H. Tanimoto and M. Nashimoto: Evaluation of cosmetic effects with a friction meter, Cosmetics \& Toiletries, 94, August, 20 24 (1979)

6）林 照次, 新井清一，遠藤さとみ，三村邦雄 : 乳 化物の官能検査とその数量化一パネルの評価能力 および評価傾向の把握一, J. Soc. Cosmet. Chem. Japan, 19 (1), 90 99 (1985). 